\title{
Short-term Inactivation Rates of Selected \\ Gram-Positive and Gram-Negative Bacteria Attached to Metal Oxide Mineral Surfaces: Role of Solution and Surface Chemistry
}

\author{
Revised and resubmitted to: \\ Environmental Science and Technology
}

April 28, 2013

BAHAREH ASADISHAD ${ }^{1}$, SUBHASIS GHOSHAL ${ }^{2}$, and NATHALIE TUFENKJI*,1

${ }^{1}$ Department of Chemical Engineering, McGill University,

Montreal, Quebec H3A 2B2, Canada

${ }^{2}$ Department of Civil Engineering, McGill University, Montreal, Quebec H3A 2K6, Canada

*Corresponding Author. Phone: (514) 398-2999; Fax: (514) 398-6678; E-mail: nathalie.tufenkji@mcgill.ca 


\section{Abstract}

Metal oxides such as ferric or aluminum oxides can play an important role in the retention of bacteria in granular aquatic environments; however, their role in bacterial inactivation is not well understood. Herein, we examined the role of water chemistry and surface chemistry on the shortterm inactivation rates of three bacteria when adhered to surfaces. To evaluate the role of water chemistry on the inactivation of attached bacteria, the loss in membrane integrity of bacteria attached to an iron oxide $\left(\mathrm{Fe}_{2} \mathrm{O}_{3}\right)$ surface was measured over a range of water ionic strengths of either monovalent or divalent salts in the absence of a growth substrate. The influence of surface chemistry on the inactivation of attached bacteria was examined by measuring the loss in membrane integrity of cells attached to three surfaces $\left(\mathrm{SiO}_{2}, \mathrm{Fe}_{2} \mathrm{O}_{3}\right.$ and $\left.\mathrm{Al}_{2} \mathrm{O}_{3}\right)$ at a specific water chemistry $(10 \mathrm{mM}$ $\mathrm{KCl}$ ). Bacteria were allowed to attach onto the $\mathrm{SiO}_{2}$ or metal oxide coated slides mounted in a parallel-plate flow cell, and their inactivation rate (loss in membrane integrity) was measured directly without removing the cells from the surface and without disturbing the system. X-ray photoelectron spectroscopy analysis revealed a high correlation between the amounts of C-metal or O-metal bonds and the corresponding bacterial inactivation rates for each surface. Finally, for all three surfaces, a consistent increase in inactivation rate was observed with the type of bacterium in the order: Enterococcus faecalis, Escherichia coli O157:H7, and Escherichia coli D21f2. 


\section{Introduction}

The occurrence of microbial pathogens in drinking water sources is recognized as an important threat to public health. A better understanding of the key processes governing the fate of microbial pathogens in groundwater aquifers or deep-bed granular filters used in water treatment operations can help mitigate the risk of drinking water contamination. The attachment of pathogens to aquifer or filter grain surfaces and the inactivation of attached and suspended pathogens are key processes that attenuate the concentration of viable pathogens in potable water supplies. ${ }^{1,2}$ Although substantial research effort has been aimed at elucidating the role of various physical, chemical and biological factors on the attachment of microorganisms to aquifer or filter grain surfaces, ${ }^{3,4}$ less is known about the factors influencing microbe inactivation in these environments. The impact of various environmental factors such as water chemistry, temperature, and organic matter content on the inactivation rate of viruses, bacteria, and/or protozoa suspended in the aqueous phase has been examined. ${ }^{2,5,6}$ However, our understanding of microbe inactivation when attached to grain surfaces is limited.

The surfaces of aquifer sediments or filter grains are commonly coated with patches of minerals such as ferric and aluminum oxides that may be positively charged at certain $\mathrm{pH}$ ranges (e.g., the $\mathrm{pH}_{\mathrm{PZC}}$ for $\mathrm{Al}_{2} \mathrm{O}_{3}$ is between 8 to 10 ). ${ }^{7-9} \mathrm{~A}$ number of researchers have demonstrated that such metal oxide coatings can provide a favorable surface for the deposition of negatively charged colloids or microorganisms and thus play an important role in their retention in granular porous matrices. ${ }^{10-14}$ It has also been shown that polyvalent cations increase attachment of bacteria ${ }^{15}$ and that the adsorption of dissolved organic matter onto iron oxides reduces adhesion by masking positive 
charge. ${ }^{12}$ Although it has been established that microbes are preferentially retained on the surface of positively charged metal oxide patches under environmentally relevant conditions, the impact of these coatings and their surface chemistry on the inactivation of retained microorganisms has not been well examined. There is limited literature on techniques to measure the loss of viability of microbes attached to natural or model surfaces in an aqueous environment. ${ }^{16-18}$ Most of the methods rely on detachment of microbes from the surface, which may damage or kill cells and thereby introduce experimental error into the measurement. ${ }^{19}$ To overcome this and other experimental challenges in evaluating the role of aquifer or filter grain surface chemistry on microbial inactivation, we recently developed an experimental technique for in situ real-time evaluation of the inactivation kinetics of bacteria adhered onto a surface in model environmental conditions. ${ }^{18}$

Poortinga et al. measured electron transfer during bacterial adhesion to indium tin oxide ${ }^{20}$ and titanium oxynitride ${ }^{21}$ coatings suggesting that chemical reactions may occur during adhesion. In another study, Kerisit et al. investigated the rate of direct electron transfer across the cytochromeiron oxide interface. ${ }^{22}$ Thus, reactions between bacterial surfaces and mineral coatings on grain surfaces could also influence the attachment and subsequent inactivation of those attached microbes.

The objective of this study is to evaluate the extent of bacterial attachment and subsequent inactivation on model grain surfaces, representative of both bare silica and metal oxide portions of aquifer or filter grains. The bare sand surface is modeled using a clean glass $\left(\mathrm{SiO}_{2}\right)$ slide whereas the metal oxide coated patches found on the surface of aquifer or filter grains are modeled using glass slides coated with thin films of iron oxide $\left(\mathrm{Fe}_{2} \mathrm{O}_{3}\right)$ or alumina $\left(\mathrm{Al}_{2} \mathrm{O}_{3}\right)$. The bare or coated glass slides are mounted in a parallel plate flow chamber (PPFC), and the extent of bacterial attachment and 
subsequent inactivation (loss in membrane integrity) of three different bacterial strains (E. coli D21f2, E. coli $\mathrm{O} 157: \mathrm{H} 7$, and E. faecalis) is examined in real-time without disturbing the experimental system. To evaluate the role of water chemistry on bacterial inactivation, the loss in membrane integrity of bacteria attached to an iron oxide $\left(\mathrm{Fe}_{2} \mathrm{O}_{3}\right)$ surface was measured over a range of solution ionic strength (IS) (1 to $100 \mathrm{mM}$ ) of either monovalent or divalent salts ( $\mathrm{KCl}$ and $\mathrm{CaCl}_{2}$ ). The influence of the substratum surface chemistry on bacterial inactivation kinetics was examined by measuring the loss in membrane integrity of cells attached to three different surfaces $\left(\mathrm{SiO}_{2}, \mathrm{Fe}_{2} \mathrm{O}_{3}\right.$ and $\left.\mathrm{Al}_{2} \mathrm{O}_{3}\right)$ at a specific water chemistry $(10 \mathrm{mM} \mathrm{KCl})$. Finally, using high resolution

X-ray photoelectron spectroscopy (XPS) analysis, the abundance of specific bonds between the bacterial cells and the three mineral surfaces was determined in an effort to assess the role of chemical bonding in the bacterial inactivation mechanism.

\section{Materials and Methods}

\section{Selection of Bacteria.}

Two Gram negative bacteria, non-pathogenic E. coli $\mathrm{D} 21 \mathrm{f} 2$ and pathogenic E. coli $\mathrm{O} 157: \mathrm{H} 7$ (ATCC 700927), and a Gram positive organism, pathogenic E. faecalis (ATCC 29212) were used as the test bacteria. E. coli $\mathrm{O} 157: \mathrm{H} 7$ was selected as a representative bacterial pathogen that may be found in contaminated drinking water supplies. E. coli D21f2 was selected as it is a wellcharacterized non-pathogenic laboratory strain of $E$. coli used in several studies of environmental fate. It is also of interest to evaluate whether the non-pathogenic E. coli D21f2 could be a good surrogate for the inactivation behavior of E. coli O157:H7. To evaluate how the bacterial cell wall 
structure may influence inactivation of cells attached to the metal oxide surfaces, E. faecalis was selected as a representative pathogenic Gram positive bacterium.

\section{Physico-chemical Characterization of Bacterial Cells.}

The electrophoretic mobility (EPM), hydrodynamic diameter and relative hydrophobicity of the selected bacteria were characterized (details are provided in the Supporting Information).

\section{Characterization of Silica and Metal Oxide Surfaces.}

A glass microscope slide (clear and corrosion-resistant silica, Fisher Scientific) was used as the bare silica surface. The glass samples coated with metal oxide films were prepared by the MicroFabrication Facility at McGill University. The 7 and 200 nm-thick films of $\mathrm{Fe}_{2} \mathrm{O}_{3}$ and $\mathrm{Al}_{2} \mathrm{O}_{3}$ were produced by low pressure chemical vapor deposition (Tylan/Tytan furnace). The thickness of the metal oxide films on the surface was determined using ellipsometry. The sputtering targets with dimensions of 3 in (diameter) $\times 0.125$ in (thickness) were 99.99\% pure $\mathrm{Fe}_{2} \mathrm{O}_{3}$ and $\mathrm{Al}_{2} \mathrm{O}_{3}$ (Kurt $\mathrm{J}$. Lesker Company).

The relative hydrophobicity of the three types of surfaces was evaluated by water contact angle measurements at room temperature using an OCA-30 goniometer (Future Digital Scientific Corp., NJ, USA) equipped with a microliter syringe. Measurements were made on sessile drops (5 $\mu \mathrm{L}$ droplets) by measuring the tangent to the drop at its intersection with the surface. Values reported are the mean of the tangents taken at both sides of five droplets. The contact angle was measured from a snapshot taken $3 \mathrm{sec}$ after the initial contact. All measurements were repeated on at least three different samples. 
The streaming potential of bare and coated glass slides was measured using an electrokinetic analyzer fitted with an asymmetric clamping cell (Anton Paar, Graz, Austria). ${ }^{23}$ The measurements were performed in triplicate at room temperature in 1,10 , and $100 \mathrm{mM} \mathrm{KCl}$ or $\mathrm{CaCl}_{2}, \mathrm{pH} 5.8$. Streaming potential measurements were converted to zeta-potentials using the modified Smoluchowski-Helmholtz formulation. ${ }^{23}$

The nature of the surface coating was also examined using XPS (VG ESCALAB 3 Mark II). The excitation source was non-monochromatic magnesium X-rays with a wavelength of $0.989 \mathrm{~nm}$ which corresponds to photon energy of 1253 for silica and alumina surfaces and nonmonochromatic aluminum X-rays with a wavelength of $0.83386 \mathrm{~nm}$ which corresponds to photon energy of $1486.7 \mathrm{eV}$ for the $\mathrm{Fe}_{2} \mathrm{O}_{3}$ surface. The binding energies for elements of interest were referenced to the binding energy of $\mathrm{C} 1 \mathrm{~s}$ at $285.0 \mathrm{eV}$.

\section{Bacterial Adhesion Experiments.}

Bacterial adhesion to all three surfaces was examined using a PPFC with dimensions of 47.5 $\mathrm{mm} \times 12.7 \mathrm{~mm} \times 1.6 \mathrm{~mm}$ (Model FC81, Biosurface Technologies). As described previously, ${ }^{18}$ the PPFC was first rinsed with ethanol and DI water using a syringe pump (Model 200, KD Scientific) at $2 \mathrm{~mL} / \mathrm{min}$ for duration of $10 \mathrm{~min}$ and then equilibrated with sterile electrolyte, either $\mathrm{KCl}$ or $\mathrm{CaCl}_{2}(1,10$ or $100 \mathrm{mM}$ IS), for $10 \mathrm{~min}$, taking care to remove all air bubbles from the system. Subsequently, bacterial suspensions $\left(-3 \times 10^{6}\right.$ cells $\left./ \mathrm{mL}\right)$ were injected into the flow cell $(0.5 \mathrm{~mL} / \mathrm{min}$, $10 \mathrm{~min})$, followed by an injection of only $\mathrm{KCl}$ or $\mathrm{CaCl}_{2}$ of equivalent concentration $(0.5 \mathrm{~mL} / \mathrm{min}$, $10 \mathrm{~min}$ ) to remove any unattached cells from the chamber. Adhered bacteria were then stained using Live/Dead BacLight viability kit, imaged by fluorescence microscopy (IX-71, Olympus), and 
enumerated with image analysis software (ImagePro). Images were acquired from the bottom slide and mid-point length of the PPFC; on the surface of the bare or coated glass slide on an hourly basis and for up to 6 hours. The top plate of the chamber was a clean microscope cover slide. The PPFC was always maintained at room temperature $\left(25^{\circ} \mathrm{C}\right)$. The images were then analyzed to calculate the number of viable and total adhered bacteria as a function of time.

All experimental variables except the bacterial strain, electrolyte composition or surface type were held constant, including cell concentration, exposure time, chamber size and solution volume. An extent of attachment $(E A)$ was quantified by normalizing the number of adhered bacteria onto the desired surface immediately following a 10-min bacteria injection $\left(N_{\mathrm{PPFC}}\right)$ by the corresponding number determined under favorable conditions for deposition $\left(N_{\mathrm{PPFC}, \text { fav }}\right)$ which represents the maximum possible number of adhered bacteria:

$$
E A=\frac{\mathrm{N}_{\mathrm{PPFC}}}{\mathrm{N}_{\mathrm{PPC}} \text {,fav }}
$$

Favourable, nonrepulsive conditions were achieved in the PPFC system by using 3aminopropyltriethoxysilane (APTES)-coated glass slides having a net positive zeta potential $(+16 \pm 2$ $\mathrm{mV}) .{ }^{18}$ Briefly, PPFC experiments were conducted using an APTES-coated glass slide and the number of attached bacteria $\left(N_{\mathrm{PPFC}, \text { fav }}\right)$ was enumerated following a 10-min injection of cells followed by a 10-min flushing of electrolyte (using the three bacteria described above, separately).

\section{Determination of Attached Bacterial Inactivation Rate.}

The viability of cells adhered to bare and coated glass surfaces was evaluated using a commercially available kit (Live/Dead BacLight viability kit, Molecular Probes) which includes two DNA-binding stains: the green fluorescent stain, SYTO-9, and the red fluorescent stain, propidium 
iodide (PI). With this kit, determination of bacterial viability is based on differences in membrane integrity. SYTO-9 labels all bacteria, whereas PI penetrates bacteria with compromised membranes. Thus, bacteria with intact membranes fluoresce green and are considered to be viable while bacteria with compromised membranes fluoresce red. ${ }^{24}$ Attached bacteria were stained by filling the chamber of the PPFC with a solution of $100 \mu \mathrm{L}$ BacLight stain in $5 \mathrm{~mL}$ electrolyte for $15 \mathrm{~min}$. To prevent photobleaching, the entire experimental setup (PPFC + tubing) was protected from light and the image acquisition time was minimized. Stained bacteria were imaged using fluorescence microscopy. Direct counts were made for at least 20 images from the center of the PPFC at each time point. As a control, the inactivation of suspended (planktonic) bacteria was also measured over the same time period in the same solution conditions, and using the same BacLight solution in a 1:1 volumetric ratio. At each time point, $5 \mu \mathrm{L}$ samples of stained planktonic cells (stored in glass vials at room temperature) were imaged by fluorescence microscopy for quantification of viable and nonviable suspended bacteria. Here, viability is defined in terms of preservation of membrane integrity as the percentage of bacterial cells with intact membranes (stained with SYTO-9) to the total number of cells. By evaluating the change in the number of viable (intact) cells as a function of time, the bacterial inactivation rate can be obtained. Specifically, the bacterial inactivation rate $\left(r_{i}\right)$ is calculated from the initial (first $3 \mathrm{~h}$ ) slope of the viability curve as the $\%$ loss of viability per hour.

To investigate the role of solution IS and cation valence on bacterial attachment and inactivation, the experiment was conducted with $\mathrm{Fe}_{2} \mathrm{O}_{3}$-coated surfaces at 1, 10, and $100 \mathrm{mM}$ IS of $\mathrm{KCl}$ or $\mathrm{CaCl}_{2}$, for the three bacterial strains. The solution chemistries tested were selected to be representative of the ions and range of IS found in natural waters. ${ }^{25}$ To further study the role of 
surface chemistry on bacterial adhesion and inactivation, the same experiment was repeated using two other substrates; namely, bare glass $\left(\mathrm{SiO}_{2}\right)$ and $\mathrm{Al}_{2} \mathrm{O}_{3}$-coated glass at a single IS $(10 \mathrm{mM} \mathrm{KCl})$. Each experiment was performed in triplicate.

XPS Analysis for Surface Characterization and Identification of Chemical Bonding between Cells and Surfaces.

The nature of the surface film before and after bacterial attachment was examined using XPS (VG ESCALAB 3 Mark II). The excitation source was non-monochromatic magnesium X-rays with a wavelength of $0.98 \mathrm{~nm}$ which corresponds to photon energy of $1253 \mathrm{eV}$ for silica and alumina surfaces and non-monochromatic aluminum X-rays with a wavelength of $0.83 \mathrm{~nm}$ which corresponds to photon energy of $1486.7 \mathrm{eV}$ for the $\mathrm{Fe}_{2} \mathrm{O}_{3}$ surface. Sample preparation involved placing $200 \mu \mathrm{L}$ of a fresh bacterial suspension (in $10 \mathrm{mM} \mathrm{KCl}$ ) on a $1 \mathrm{~cm}^{2}$ sample of bare or coatedglass surface for $3 \mathrm{~h}$ which is the same length of time as that used to evaluate the initial inactivation rate. Next, the excess cell suspension was removed using a pipette. The surfaces were rinsed with 10 $\mathrm{mM} \mathrm{KCl}$ to remove the unattached cells. As a control, the same surfaces with no exposure to bacteria were also prepared. The constant pass energy of the analyzer for high resolution scan was $20 \mathrm{eV}$ and it was calibrated with reference to the binding energy of $\mathrm{C} 1 \mathrm{~s}$ at $285.0 \mathrm{eV}$. The spectra were recorded following the sequence C1s, O1s, N1s, Si2p, Fe2p, and Al2p. 


\section{Results and Discussion}

\section{Bacteria Properties.}

Cell surface charge has been shown to play an important role in bacterial attachment to surfaces $^{26}$; hence, the cell surface (zeta) potential was evaluated from EPM measurements conducted over the range of experimental conditions investigated. The zeta potentials of the $E$. coli D21f2, $E$. coli $\mathrm{O} 157: \mathrm{H} 7$ and E. faecalis cells indicate that all three bacterial strains used in this study were negatively charged over the range of IS and at the $\mathrm{pH}(5.6-5.8)$ examined. The zeta potential results are presented in Figure S1. For E. coli D21f2 and E. faecalis, the absolute magnitude of the cell zeta potential decreased with an increase in IS of either $\mathrm{KCl}$ or $\mathrm{CaCl}_{2}$, as expected based on compression of the electrical double layer. ${ }^{27}$ In contrast, for E. coli O157:H7, the cell zeta potential remained close to neutral over a range of IS in both electrolytes. The other bacteria exhibited a much more negative zeta potential when suspended in $\mathrm{KCl}$ versus $\mathrm{CaCl}_{2}$ solutions. This is likely due to $\mathrm{Ca}^{2+}$ electrical charge screening and complexation with bacteria surface proteins resulting in charge neutralization. ${ }^{28}$ The bacterium with the least negative zeta potential was E. coli O157:H7 in either $\mathrm{KCl}$ or $\mathrm{CaCl}_{2}$ solution $(\sim-2 \mathrm{mV})$, while the most negatively charged bacterium was $E$. coli $\mathrm{D} 21 \mathrm{f} 2$ in $\mathrm{KCl}$ solution $(-25 \mathrm{mV}$ in $1 \mathrm{mM} \mathrm{KCl})$. These zeta potential values were used to calculate the DLVO interaction energy profiles between the bacteria and the iron oxide surface, which are discussed later in the paper.

The hydrodynamic diameter of all three bacteria measured by DLS (Table S1) and confirmed by scanning electron microscopy was approximately $1.3 \pm 0.17 \mu \mathrm{m}$. Also, it was observed that the size of the cells was not greatly affected by the presence of either $\mathrm{K}^{+}$or $\mathrm{Ca}^{2+}$ (Table S1). 
These data suggest that the variation in bacterial adhesion observed for the different bacteria in the presence of the monovalent versus divalent cations cannot be attributed to changes in cell size.

\section{Properties of Silica and Metal Oxide Surfaces.}

The relative hydrophobicity of the three surfaces was determined by water contact angle measurements. The bare glass had the most hydrophilic surface (contact angle: $8^{\circ}$, Table S2). A contact angle of $65^{\circ}$ was measured for the $\mathrm{Fe}_{2} \mathrm{O}_{3}$ surface, and $60^{\circ}$ for the alumina surface (Table S2). The bare glass and metal oxide surfaces were negatively charged in all conditions, except for alumina in 1 to $100 \mathrm{mM} \mathrm{KCl}$ and in $100 \mathrm{mM} \mathrm{CaCl}$. The zeta potential values ranged from -40 to $-6 \mathrm{mV}$ for silica, -15 to -1.7 for $\mathrm{Fe}_{2} \mathrm{O}_{3}$, and -11 to +8 , for alumina (Table S2). The thin film of $\mathrm{Fe}_{2} \mathrm{O}_{3}(7 \mathrm{~nm})$ acquired negative charge in the range of tested IS which is in accordance with a previous study. ${ }^{13}$ In general, the surface charge should be more positive for a thicker metal oxide layer. ${ }^{29}$ The absolute magnitude of the surface zeta potential decreased with an increase in IS of either $\mathrm{KCl}$ or $\mathrm{CaCl}_{2}$ for all three surfaces. These zeta potential values (Table S2) were used in the DLVO interaction energy calculations between the bacteria and the surfaces (Table 1). 


\begin{tabular}{|c|c|c|c|c|c|c|c|c|}
\hline \multirow[b]{3}{*}{ IS (mM) } & \multicolumn{6}{|c|}{ Bacteria Attached onto Iron oxide $\left(\mathrm{Fe}_{2} \mathrm{O}_{3}\right)$} & \multirow{2}{*}{\multicolumn{2}{|c|}{$\frac{\text { Planktonic }^{\mathrm{c}}}{r_{i}(\% / \mathrm{h})}$}} \\
\hline & \multicolumn{2}{|c|}{$\Phi_{\max }\left(k_{\mathrm{B}} \mathrm{T}\right)^{\mathrm{a}}$} & \multicolumn{2}{|c|}{$E A^{c}$} & \multicolumn{2}{|c|}{$r_{i}(\% / \mathrm{h})$} & & \\
\hline & $\mathrm{K}^{+}$ & $\mathrm{Ca}^{2+}$ & $\mathrm{K}^{+}$ & $\mathrm{Ca}^{2+}$ & $\mathrm{K}^{+}$ & $\mathrm{Ca}^{2+}$ & $\mathrm{K}^{+}$ & $\mathrm{Ca}^{2+}$ \\
\hline \multicolumn{9}{|c|}{ E. coli D2lf2 } \\
\hline 1 & 351 & $\mathrm{NB}$ & 0.2 & 0.3 & $8.3 \pm 0.7$ & $2.1 \pm 0.4$ & 0.2 & 0.4 \\
\hline 10 & $\mathrm{NB}^{b}$ & NB & 0.4 & 0.6 & $3.1=0.9$ & $1.3=02$ & 0.5 & 0 \\
\hline 100 & $\mathrm{NB}$ & $\mathrm{NB}$ & 0.5 & 1.0 & $1.3=0.6$ & $0.5=0.5$ & 0 & 0 \\
\hline \multicolumn{9}{|c|}{ E. coli $0157: \mathrm{H}^{7}$} \\
\hline 1 & $\overline{N B}$ & NB & 0.5 & 0.5 & $6.0 \pm 0.7$ & $2.6 \pm 0.6$ & 0 & 0 \\
\hline 10 & NB & NB & 0.6 & 0.9 & $2.0=0.9$ & $1.8=0.9$ & 0 & 0 \\
\hline 100 & $\mathrm{NB}$ & $\mathrm{NB}$ & 0.7 & 0.9 & $0.0=0.0$ & $1.5=0.6$ & 0 & 0 \\
\hline \multicolumn{9}{|l|}{ E-faecalis } \\
\hline 1 & 126.3 & $\mathrm{NB}$ & 0.3 & 0.6 & $0.5 \pm 0.5$ & $0 \pm 0.0$ & 0.3 & 0 \\
\hline 10 & $\mathrm{NB}$ & $\mathrm{NB}$ & 0.5 & 0.7 & $0.1=0.1$ & $0=0.0$ & 0 & 0 \\
\hline 100 & NB & $\mathrm{NB}$ & 0.6 & 0.8 & $0.1=0.1$ & $0=0.0$ & 0 & 0 \\
\hline
\end{tabular}

${ }^{\mathrm{a}}$ Hamaker constant of $3.22 \times 10^{-20} \mathrm{~J}$ was used to calculate interaction energies. $k_{\mathrm{B}}$ :

Boltamann constant, $1.3805 \times 10-23 \mathrm{~J} / \mathrm{K}, \mathrm{T}$ : absolute temperature, ${ }^{b} \mathrm{NB}$ refers to no energy barrier, "Standard deviations for $r_{i}$ for planktoric cells and for $E 4$ are not shown as they were found to be $<0.05$.

Table 1. Energy barriers $\left(\Phi_{\max }\right)$, extent of attachment $(E A)$, and inactivation rates $\left(r_{i}\right)$ of all three bacterial strains adhering onto $\mathrm{Fe}_{2} \mathrm{O}_{3}$ surface at various ionic strengths of $\mathrm{KCl}$ and $\mathrm{CaCl} . \mathrm{r}_{i}$ values are also provided for planktonic (suspended) cells.

The presence of iron and aluminum elements on the surface of the coated slides was confirmed using XPS analysis. Table $\mathrm{S} 3$ shows the elemental analysis for silica, $\mathrm{Fe}_{2} \mathrm{O}_{3}$, and $\mathrm{Al}_{2} \mathrm{O}_{3}$ surfaces. The silica surface spectra contained two major peaks for O1s and Si2p at $532.82 \mathrm{eV}$ and $103.23 \mathrm{eV}$, with relative quantities of $62.36 \%$ and $21.59 \%$, respectively. For the $\mathrm{Fe}_{2} \mathrm{O}_{3}$ surface, the survey showed peak binding energies at 712.07 and $531.45 \mathrm{eV}$ for Fe2p3 (corresponding to Fe(III) in $\mathrm{Fe}_{2} \mathrm{O}_{3}$ ) and $\mathrm{O} 1$ s, respectively contributing to $13.4 \%$ and $60.4 \%$ of the surface. On the $\mathrm{Al}_{2} \mathrm{O}_{3}$ coated slide, the relative quantities of $\mathrm{O} 1 \mathrm{~s}$ and $\mathrm{Al} 2 \mathrm{p}\left(\mathrm{in}_{\mathrm{Al}_{2} \mathrm{O}_{3}}\right.$ ) were $54.2 \%$ and $21.3 \%$ at $531.12 \mathrm{eV}$ 
and $74.03 \mathrm{eV}$, respectively. Thus, the XPS analysis confirmed the presence of $\mathrm{Fe}_{2} \mathrm{O}_{3}$ and $\mathrm{Al}_{2} \mathrm{O}_{3}$ deposited on the silica surface.

\section{Effect of Solution Chemistry on Bacterial Adhesion and Inactivation Rate.}

To investigate the role of water chemistry on the extent of attachment and subsequent inactivation of attached bacteria, experiments were conducted over a range of IS (1 to $100 \mathrm{mM}$ ) of both monovalent and divalent salt solutions for a single surface $\left(\mathrm{Fe}_{2} \mathrm{O}_{3}\right)$ (Table 1). As this study focuses on the inactivation of attached bacteria, it was of interest to first evaluate the extent of bacterial adhesion $(E A)$. For all three bacteria, there was an increase in the $E A$ with increasing IS of either $\mathrm{KCl}$ or $\mathrm{CaCl}_{2}$. The ratio $E A$ appears to reach maximum values of $0.5,0.7$, and 0.6 in $\mathrm{KCl}$ and approach 1, 0.9, and 0.8 in $\mathrm{CaCl}_{2}$ for E. coli $\mathrm{D} 21 \mathrm{f} 2$, E. coli $\mathrm{O} 157: \mathrm{H} 7$, and E. faecalis adhering onto the $\mathrm{Fe}_{2} \mathrm{O}_{3}$ surface, respectively. Among the tested bacteria, E. coli O157:H7 exhibits the highest adhesion in either $\mathrm{KCl}$ or $\mathrm{CaCl}_{2}$ when depositing onto $\mathrm{Fe}_{2} \mathrm{O}_{3}$. In general, bacteria suspended in $\mathrm{KCl}$ adhered less as compared with cells suspended in $\mathrm{CaCl}_{2}$ solution where the cells were less negatively charged (Figure S1) and more hydrophobic (Table S1). These variations in adhesion behavior may be attributed to cell electrokinetic properties, surface charge, cell hydrophobicity, and cell surface structures. ${ }^{29,30}$

To better understand the differences in $E A$ measured in $\mathrm{KCl}$ and $\mathrm{CaCl}_{2}$ solutions for all three bacteria, the classical DLVO theory ${ }^{31,32}$ is considered and the bacteria-surface interaction energy calculations are presented as the height of the repulsive energy barrier $\left(\Phi_{\max }\right)$ in Table 1 (details regarding the DLVO calculations are provided in Supporting Information). The DLVO 
calculations (Table 1) reveal the presence of a repulsive energy barrier to deposition onto $\mathrm{Fe}_{2} \mathrm{O}_{3}$ under two experimental conditions only. For each bacterium, the predicted presence of an interaction energy barrier corresponded to the lowest values of $E A$ observed.

Although previous studies aimed at understanding the fate of bacteria in aquatic environments have previously examined the role of water chemistry on adhesion, ${ }^{28,29,33,34}$ those studies have not attempted to quantify the loss in bacterial viability with time; namely, the bacterial inactivation rate for cells remaining attached on the substratum. Here, viability is defined in terms of preservation of membrane integrity as the percentage of bacterial cells with intact membranes to the total number of attached cells. Bacteria were mostly viable (viability>90\%) at the beginning of each experiment (when they first adhered onto the $\mathrm{Fe}_{2} \mathrm{O}_{3}$ surface) and there was a decrease in the observed viability over time (Figure S2). The initial rate of bacterial inactivation for each bacterial strain can be evaluated from the initial slopes of the curves presented in Figure S2 (i.e., from the linear portion of the curves, between $t=0$ and $3 \mathrm{~h}$ )..$^{18}$ The bacterial inactivation rates are plotted in Figure 1 as the loss in viability with time $\left(r_{\mathrm{i}}\right)\left(\%\right.$ loss/h) of cells attached onto $\mathrm{Fe}_{2} \mathrm{O}_{3}$ for different solution IS of either monovalent or divalent cations. The data is also summarized in Table 1 for direct comparison with the values of $\Phi_{\max }$ and $E A$.

Figure 1 suggests that the effect of solution chemistry was more pronounced for E. coli D21f2 and for E. coli O157:H7, whereas for E. faecalis, there was no significant change in inactivation rate of the adhered cells. The pathogenic E. coli $\mathrm{O} 157: \mathrm{H} 7$ displays a comparable ability to survive on $\mathrm{Fe}_{2} \mathrm{O}_{3}$ as the non-pathogenic E. coli $\mathrm{D} 21 \mathrm{f} 2$ in $\mathrm{CaCl}_{2}$ solution (Figure 1b), where the inactivation rates were $2.1 \% / \mathrm{h}$ and $2.6 \% / \mathrm{h}$ in $1 \mathrm{mM} \mathrm{CaCl}$ and $1.3 \% / \mathrm{h}$ and $1.8 \% / \mathrm{h}$ in $10 \mathrm{mM}$ 
$\mathrm{CaCl}_{2}$ for E. coli $\mathrm{D} 21 \mathrm{f} 2$ and E. coli $\mathrm{O} 157: \mathrm{H} 7$, respectively. However, the attached non-pathogenic E. coli D21f2 was more vulnerable in $\mathrm{KCl}$ solution (Figure 1a). Moreover, E. faecalis 29212, a representative Gram-positive bacterium, exhibited a lower inactivation rate in comparison to the two E. coli strains and was hence more resistant in the attached mode at the experimental conditions examined here. For comparison, the inactivation rates of suspended (planktonic) cells are also included in Table 1 . These data show that bacterial viability was generally higher when the cells were suspended versus attached on $\mathrm{Fe}_{2} \mathrm{O}_{3}$ (for all solution chemistries).
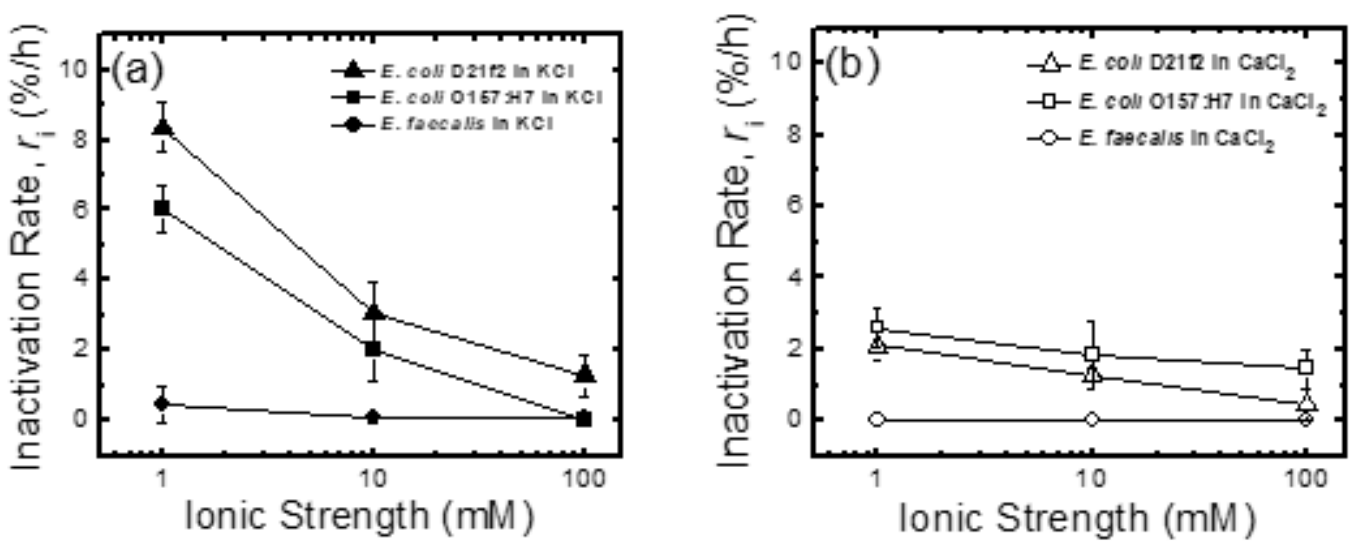

Figure 1. Inactivation rates based on Live/Dead BacLight viability measurements for different solution ionic strengths (1, 10, and $100 \mathrm{mM}$ ) of (a) $\mathrm{KCl}$ and (b) $\mathrm{CaCl}_{2}$ for E. coli D21f2, E. coli O157:H7, and E. faecalis adhered onto $\mathrm{Fe}_{2} \mathrm{O}_{3}$. The error bars indicate standard deviations.

In general, under all conditions, the three bacteria attached onto $\mathrm{Fe}_{2} \mathrm{O}_{3}$ exhibited the highest inactivation rate in the lowest IS solution. When decreasing the solution IS, the cell inactivation rate increased more significantly in $\mathrm{KCl}$ versus $\mathrm{CaCl}_{2}$. High osmotic pressure and electrolyte imbalance across the cell membrane are proposed to be the causes of low cell viability at low IS. ${ }^{35}$ However, high viability of planktonic cells over a period of $6 \mathrm{~h}$ under all conditions (Table 1) suggests that 
other mechanisms are involved in bacterial inactivation when the cells are attached to the surface at low IS.

\section{Influence of Surface Chemistry on Bacterial Adhesion and Inactivation Rate.}

To better understand the role of substratum surface chemistry on the inactivation of attached cells, we examined the inactivation of bacteria attached on three different surfaces; namely, silica, $\mathrm{Fe}_{2} \mathrm{O}_{3}$, and $\mathrm{Al}_{2} \mathrm{O}_{3}$ at a specific solution chemistry $(10 \mathrm{mM} \mathrm{KCl}, \mathrm{pH}$ 5.8).

Figure 2a shows the $E A$ for all three bacteria on the three surfaces at $10 \mathrm{mM} \mathrm{KCl}$. For each organism, the lowest $E A$ was observed on silica and the highest $E A$ was measured on alumina which was positively charged (Figure 2a). On the silica surface, for all three strains, the initial inactivation rate was less than $2 \% / \mathrm{h}$ (Figure $2 \mathrm{~b}$ ) and there was no significant change in viability over a 6 hour period (data not shown). For the pathogenic E. coli, the inactivation rates were comparable on the $\mathrm{Fe}_{2} \mathrm{O}_{3}(-2 \% / \mathrm{h})$ and $\mathrm{Al}_{2} \mathrm{O}_{3}$ surfaces $(-3 \% / \mathrm{h})$ (Figure $\left.2 \mathrm{~b}\right)$. The non-pathogenic E. coli D21f2 exhibits the highest inactivation rate $(-4 \% / \mathrm{h})$ on the alumina surface. For all three surfaces examined, the viability of attached bacteria was greater than $90 \%$ at the beginning of each experiment (when they first adhered) and there was a decrease in the observed viability over time, similar to the patterns shown in Figure S2. Of the two metal oxide surfaces, alumina exhibits a greater antimicrobial effect on adhered $E$. coli cells due to its net positive surface charge ${ }^{17,36-40}$ compared to the negatively charged $\mathrm{Fe}_{2} \mathrm{O}_{3}$. Metal ions such as silver ions and metal oxides such as zinc oxide, copper oxide, and aluminum oxide have been shown to exhibit antimicrobial properties. ${ }^{41-43}$ For instance, reductions of more than $5 \log _{10} \mathrm{CFU} / \mathrm{mL}$ of both Staphylococcus aureus and E. coli were confirmed after 90 min of 
treatment with a silver ion solution. ${ }^{41}$ In another study, $8.2 \%$ reduction in culturability was reported for Pseudomonas chlororaphis $\mathrm{O} 6$ after $60 \mathrm{~min}$ exposure to $\mathrm{ZnO}$ and $\mathrm{CuO}^{42} \mathrm{In}$ addition, a mild growth inhibitory effect of aluminum oxide nanoparticles were reported for E. coli. ${ }^{43}$ A $60 \%$ growth reduction was observed over a 24-hour period for $P$. aeruginosa in the presence of $250 \mu \mathrm{g} / \mathrm{mL} \mathrm{Al}_{2} \mathrm{O}_{3}$ nanoparticles. ${ }^{44}$ In the same study, $\mathrm{ZnO}$ reduced the growth of $S$. aureus and $P$. aeruginosa by $62 \%$ and $49 \%$, respectively. ${ }^{44}$ In these studies, the bacteria and the metal oxide particles were suspended in a liquid phase, whereas in our study, inactivation occurred after bacterial attachment to the substratum.

Terada et al. $^{45}$ investigated the effect of substratum surface charge on E. coli adhesion and survival, and found that electrostatic attraction forces induced more bacterial retention and lower viability. In the present study, comparing the results of $E A$ and $r_{\mathrm{i}}$ (Figure 2) shows that there was no correlation between the extent of attachment and inactivation rate for the tested bacterial strains when considering all three surfaces. For instance, E. coli O157:H7 exhibited higher attachment than E. coli $\mathrm{D} 21 \mathrm{f} 2$ on $\mathrm{Fe}_{2} \mathrm{O}_{3}$ in $10 \mathrm{mM} \mathrm{KCl}$ but its inactivation rate was lower. In another example, $E$. faecalis exhibited comparable attachment to the other tested strains on $\mathrm{Fe}_{2} \mathrm{O}_{3}$, but it had the lowest inactivation rate. 

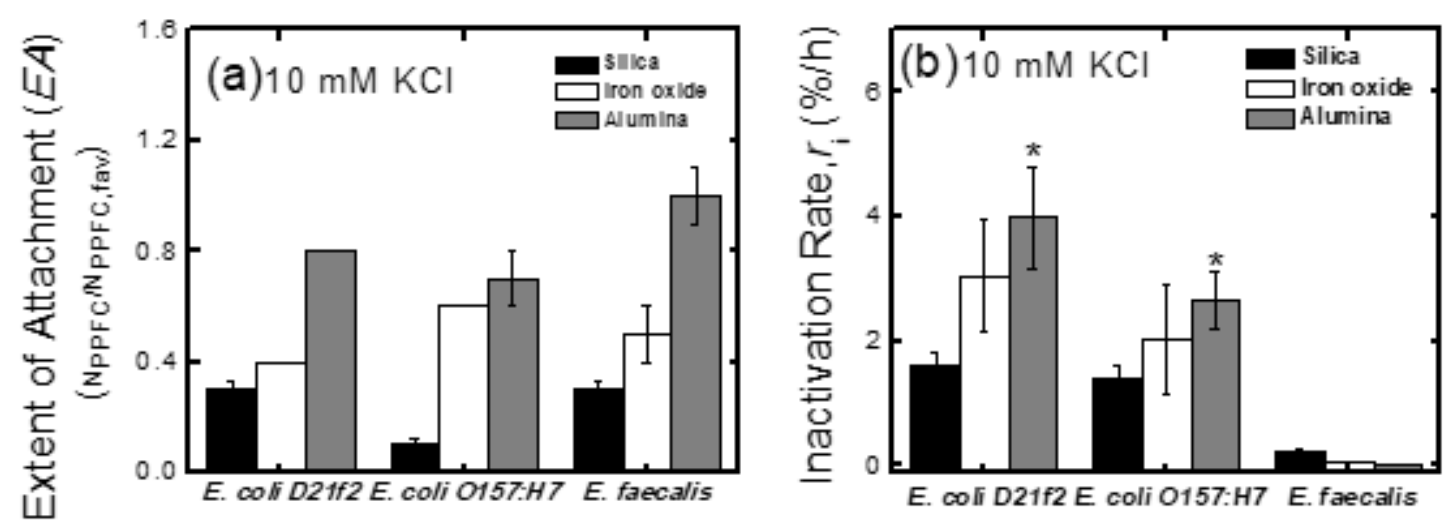

Figure 2. (a) Extent of bacterial attachment (EA) and (b) inactivation rates ( $\left.r_{i}\right)$ for E. coli D21f2, E. coli O157:H7, and E. faecalis adhered to different surfaces (silica, $\mathrm{Fe}_{2} \mathrm{O}_{3}$, and $\mathrm{Al}_{2} \mathrm{O}_{3}$ ) in $10 \mathrm{mM} \mathrm{KCl}$. The error bars indicate standard deviation. An asterisk indicates statistically significant difference in inactivation rates when compared to the silica treatment (determined using one-way ANOVA, $p<$ 0.005).

A potential mechanism that could play a role in bacterial inactivation is loss of membrane structural integrity as a result of interactions between bacteria and minerals. ${ }^{46}$ It has been shown that different constituents in cell walls of Gram-positive and Gram-negative bacteria are capable of binding metal ions because of exposed anionic charges associated with them. ${ }^{47}, 48$ In this study, for each bacterium, different inactivation rates were observed on surfaces with different chemistry. The selected representative Gram-positive bacterium exhibited the highest resistance on all three surfaces. To determine how the nature of the chemical bonding between the cells and the surfaces may contribute to bacterial inactivation, XPS analysis was used to characterize the cell-surface bonding chemistry. Among different chemical bonds identified using high resolution XPS analysis, the chemical bonds of particular interest to this study were the ones between the oxygen or carbon elements of cell surface functional groups and the metals ( $\mathrm{Si}, \mathrm{Fe}$, and $\mathrm{Al}$ ) on the adhering surface (Figures 3 and S3). XPS is a surface chemical analysis technique which does not penetrate the entire cell depth. Because the X-ray cannot penetrate the entire cell depth, the angled X-ray beam is 
actually probing the bare surface where there are no cells as well as the edges where bacteria meet the surface (i.e., the bacteria periphery). The analyzed area for each surface was $2 \mathrm{~mm} \times 3 \mathrm{~mm}$. In Figure 3, the relative atomic abundance of O-metal or C-metal bonds (evaluated by XPS) was normalized by the number of adhered cells for each surface (this data is represented by the bar graphs). This was achieved by dividing the relative atomic abundance (\%) of O-metal or C-metal bonds by the relative atomic abundance (\%) of nitrogen (N1s) for each bacterial strain on each surface. As $\mathrm{N}$ is only present in cells and not on the adhering surfaces (according to XPS survey of bare surfaces, Table S3), this element provides a fair estimate of the amount of adhered cells. The XPS analysis reveals the presence of $\mathrm{C}$-metal bonds on each type of surface $\left(\mathrm{SiO}_{2}, \mathrm{Fe}_{2} \mathrm{O}_{3}\right.$, and $\left.\mathrm{Al}_{2} \mathrm{O}_{3}\right)$. This type of bond is not present on the bare surfaces and, thus, the detected C-metal bonds result from bacterial attachment to the surfaces. The interpretation of the abundance of O-metal bonds is more challenging because XPS will also detect the $\mathrm{O}$ atoms bound to $\mathrm{Al}, \mathrm{Fe}$, or $\mathrm{Si}$ in the bare surfaces. Nonetheless, the data in Figure 3 do confirm that XPS detects the contribution of O-metal bonds from the bacterium-surface interface as the technique is sensitive enough to distinguish the different relative amounts of this bond when the three different bacteria are attached to a given surface (e.g., Figure 3d).

The normalized atomic abundance of C-metal and O-metal bonds and corresponding bacterial inactivation rates are plotted for all three bacterial strains adhered onto different surface chemistries (Figure 3). As clearly illustrated in Figure 3, the abundance of C-metal or O-metal covalent bonds was highly correlated with the corresponding inactivation rate of the adhering bacteria on a given surface. For instance, $R$-squared values were $0.997,0.999$, and 0.894 for linear 
regressions between the normalized amounts of C-metal bonds and measured bacterial inactivation rates for silica, $\mathrm{Fe}_{2} \mathrm{O}_{3}$, and $\mathrm{Al}_{2} \mathrm{O}_{3}$ surfaces, respectively (Figure 3a-c). The same trend was observed for O-metal bonds for all three bacteria adhered onto the three different surfaces (Figure 3d-f).

The inactivation of bacteria following adhesion onto or interaction with different minerals has been the subject of selected recent studies. Cai et al. ${ }^{46}$ recently reported that goethite significantly reduces the viability of attached E. coli $\mathrm{O} 157: \mathrm{H} 7$. These researchers proposed that the stronger and closer association between positively-charged goethite and bacteria is responsible for the observed lower bacterial viability as compared to cells bound to negatively-charged montmorillonite and kaolinite. Additionally, they hypothesized that the needle-shaped goethite structure can pierce the cell membrane thereby causing cell death. ${ }^{46}$ Another study suggests that the antibacterial mechanism of natural clay (illite-smectite or kaolin) is caused by released $\mathrm{Fe}^{2+}$ which suppresses outer membrane regulatory proteins by oxidizing to $\mathrm{Fe}^{3+}$ and forming toxic hydroxyl radicals. ${ }^{49}$ In our study, we observed a direct link between the nature of the bacteria-surface chemical bonding and the loss in cell membrane integrity. These data suggest that bacteria were more likely to become inactivated when attached to a surface with a greater number of covalent bonds; namely, C-metal or O-metal bonds. Although we observe a correlation between the abundance of C- or O-metal bonds and the extent of bacterial inactivation, the XPS analysis does not prove a causative effect. Further studies are needed to better understand the link between the type and abundance of bacteria-surface bonds and the underlying mechanisms of bacterial inactivation.

The Gram-positive bacterium exhibited the lowest extent of inactivation on the three surfaces. It is interesting that this bacterium appeared to form fewer bonds with the metals on the 
surface (Figure 3). It has been shown that the metal binding ability of Gram-positive Bacillus subtilis is influenced by the proton motive force..$^{50}$ In metabolically active cells, there is competition between protons and metal ions for anionic wall sites, resulting in less metal bonds in live cells compared to non-living cells. ${ }^{50}$ 

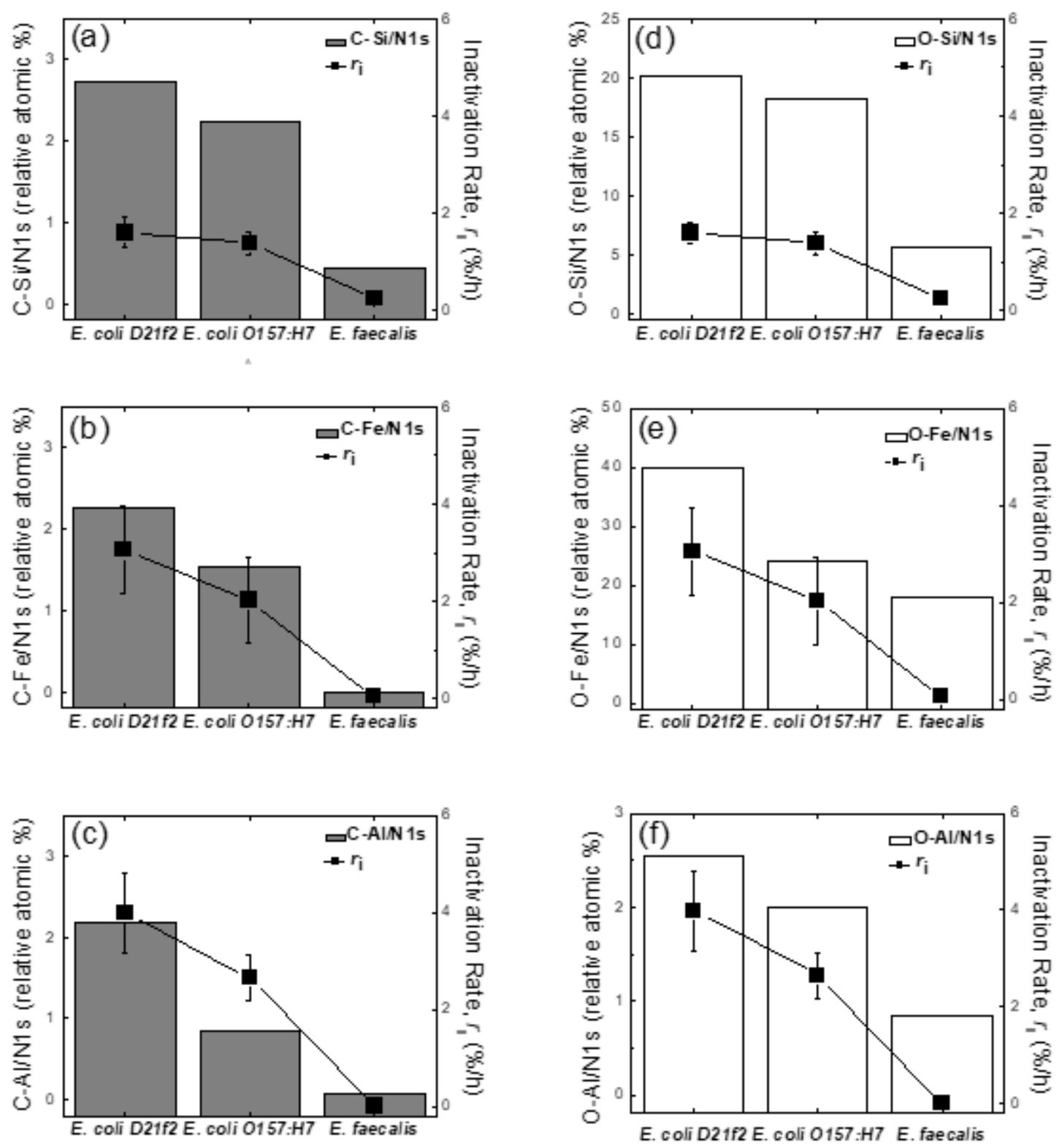

Figure 3. Comparison of the normalized atomic abundance (\%) of (a-c) C-metal bonds and (d-f) Ometal bonds formed between $(a, d)$ silica, $(b, e) \mathrm{Fe}_{2} \mathrm{O}_{3}$, and $(c, f) \mathrm{Al}_{2} \mathrm{O}_{3}$ surfaces and the adhered cells identified by high resolution XPS analysis with the corresponding inactivation rates. The error bars indicate standard deviation for $r_{i}$. The standard deviation for amount of $C$-metal and O-metal bonds was less than 0.005 .

The experiments presented here were conducted using bare glass (to mimic a sand surface as it is mainly composed of silica) and metal oxide-coated glass (to mimic patches that may be present 
on the surface of aquifer or filter grains). The effect of both solution and surface chemistry on the inactivation of adhered cells was investigated. The results show that solution chemistry plays an important role in bacterial adhesion and inactivation. Lower solution IS led to higher inactivation rates of attached bacteria and all the tested strains had higher inactivation rates in $\mathrm{KCl}$ compared to $\mathrm{CaCl}_{2}$. We also observed some variability in the inactivation behavior of the three bacterial strains when adhered on a given surface. Such differences in inactivation rates can presumably be attributed to differences in the structure and composition of the external cell wall of the selected bacteria. ${ }^{17}$ Moreover, each bacterial strain exhibited a statistically significant difference in its inactivation rate on alumina (when compared to the silica surface) which can be linked to the net positive charge of the alumina. Other studies have also reported that positively charged surfaces exert an antimicrobial effect on adhering bacteria, while negatively charged surfaces have negligible effects on bacterial viability or metabolic activity. ${ }^{16,18,46}$

There are a number of reported laboratory studies of the effects of surfaces on bacterial activity. $39,51,52$ Attachment of bacteria to surfaces can lead to enhanced or reduced bioactivity depending on the surface properties and charge, ${ }^{53-56}$ and it has been also suggested that some bacteria attach to specific surfaces as a survival strategy, ${ }^{57,58}$ but there are also examples of studies where association with a surface had no effect on bacterial activity. ${ }^{59,60}$

In this study, we found that attachment of cells to these model solid surfaces can lead to formation of covalent bonds, specifically O- and C-metal bonds, between the cell and the surface, and this results in reduced bacterial viability (i.e., cell membrane integrity). This knowledge is vital 
for understanding how cells interact with solid surfaces as well as how they become inactivated after adhering to surfaces under environmentally relevant conditions.

The results from this study show promise that it may be eventually possible to estimate the rates of inactivation of attached pathogens by accounting for the mineral surface chemistry of sediments, or, barrier materials to inactivate pathogens can be identified based on mineral surface chemistry. 


\section{Acknowledgements}

This research was supported by the Canadian Water Network, the Natural Sciences and Engineering Research Council of Canada (NSERC), the McGill Engineering Doctoral Award Program (MEDA), and the Fonds québécois de la recherche sur la nature et les technologies (FQRNT). The authors acknowledge Mrs. S. Poulin (Ecole Polytechnique, Montreal) for the XPS analysis and the McGill Micro-Fabrication Facility.

\section{Supporting Information}

Details regarding Live/Dead bacterial viability data and bacterial characterizations such as MATH assay, XPS analysis, as well as figures and tables showing supplementary data. This information is available free of charge via the Internet at http://pubs.acs.org/. 


\section{Literature Cited}

1. Pedley, S.; Yates, M.; Schijven, J. F.; West, J.; Howard, G.; Barrett, M. Pathogens: Health relevance, transport and attenuation. In Protecting Ground Water for Health, World Health Organization: 2006; pp 135.

2. Tufenkji, N.; Emelko, M. B. Fate and transport of microbial contaminants in groundwater. In Encyclopedia of Environmental Health, Elsevier: Nriagu JO Burlington, 2011; Vol. 2, pp 715-726.

3. Tufenkji, N. Modeling microbial transport in porous media: Traditional approaches and recent developments. Adv. Water Resour. 2007, 30 (6-7), 1455-1469.

4. Harvey, R. W.; Harms, H.; Landkamer, L. Transport of microorganisms in the terrestrial subsurface: in situ and laboratory methods. In Manual of Environmental Microbiology ASM Press: Washington, 2007; pp 872-897.

5. Yates, M. V.; Yates S. R.; Gerba, C. P. Modeling microbial fate in the subsurface environment. Crit. Rev. Environ. Control 1988, 17 (4), 307 - 344.

6. John, D. E.; Rose, J. B. Review of factors affecting microbial survival in groundwater. Environ. Sci. Technol. 2005, 39 (19), 7345-7356.

7. Coston, J. A.; Fuller, C. C.; Davis, J. A. $\mathrm{Pb}^{2+}$ and $\mathrm{Zn}^{2+}$ adsorption by a natural aluminum- and ironbearing surface coating on an aquifer sand. Geochim. Cosmochim. Acta 1995, 59 (17), 3535-3547.

8. Ryan, J. N.; Gschwend, P. M. Effect of iron diagenesis on the transport of colloidal clay in an unconfined sand aquifer. Geochim. Cosmochim. Acta 1992, 56 (4), 1507-1521.

9. Yopps, J. A.; Fuerstenau, D. W. The zero point of charge of alpha-alumina. J. Colloid Sci. 1964, 19 (1), 61-71.

10. Metge, D. W.; Harvey, R. W.; Aiken, G. R.; Anders, R.; Lincoln, G.; Jasperse, J.; Hill, M. C. Effects of sediment-associated extractable metals, degree of sediment grain sorting, and dissolved organic carbon upon Cryptosporidium parvum removal and transport within riverbank filtration sediments, Sonoma County, California. Environ. Sci. Technol. 2011, 45 (13), 5587-5595.

11. Abudalo, R. A.; Bogatsu, Y. G.; Ryan, J. N.; Harvey, R. W.; Metge, D. W.; Elimelech, M. Effect of ferric oxyhydroxide grain coatings on the transport of bacteriophage PRD1 and Cryptosporidium parvum Oocysts in saturated porous media. Environ. Sci. Technol. 2005, 39 (17), 6412-6419.

12. Johnson, W. P.; Martin, M. J.; Gross, M. J.; Logan, B. E. Facilitation of bacterial transport through porous media by changes in solution and surface properties. Colloids Surf., A 1996, 107, 263-271.

13. Li, B.; Logan, B. E. Bacterial adhesion to glass and metal-oxide surfaces. Colloids Surf., B 2004, 36 (2), 81-90.

14. Ryan, J. N.; Elimelech, M.; Ard, R. A.; Harvey, R. W.; Johnson, P. R. Bacteriophage PRD1 and silica colloid transport and recovery in an iron oxide-coated sand aquifer. Environ. Sci. Technol. 1999, 33 (1), 63-73.

15. Simoni, S. F.; Bosma, T. N. P.; Harms, H.; Zehnder, A. J. B. Bivalent cations increase both the subpopulation of adhering bacteria and their adhesion efficiency in sand columns. Environ. Sci. Technol. 2000,34 (6), 1011-1017.

16. van der Mei, H. C.; Rustema-Abbing, M.; Langworthy, D. E.; Collias, D. I.; Mitchell, M. D.; Bjorkquist, D. W.; Busscher, H. J. Adhesion and viability of waterborne pathogens on p-DADMAC coatings. Biotechnol. Bioeng. 2008, 99 (1), 165-169.

17. Terada, A.; Yuasa, A.; Kushimoto, T.; Tsuneda, S.; Katakai, A.; Tamada, M. Bacterial adhesion to and viability on positively charged polymer surfaces. Microbiol. 2006, 152 (12), 3575-3583. 
18. Asadishad, B.; Ghoshal, S.; Tufenkji, N. Method for the direct observation and quantification of survival of bacteria attached to negatively or positively charged surfaces in an aqueous medium. Environ. Sci. Technol. 2011, 45 (19), 8345-8351.

19. Rose, L. J.; Donlan, R.; Banerjee, S. N.; Arduino, M. J. Survival of Yersinia pestis on environmental surfaces. Appl. Environ. Microbiol. 2003, 69 (4), 2166-2171.

20. Poortinga, A. T.; Bos, R.; Busscher, H. J. Measurement of charge transfer during bacterial adhesion to an indium tin oxide surface in a parallel plate flow chamber. J. Microbiol. Methods 1999, 38 (3), 183-189.

21. Poortinga, A. T.; Bos, R.; Busscher, H. J. Charge transfer during staphylococcal adhesion to TiNOX coatings with different specific resistivity. Biophys. Chem. 2001, 91 (3), 273-279.

22. Kerisit, S.; Rosso, K. M.; Dupuis, M.; Valiev, M. Molecular computational investigation of electrontransfer kinetics across cytochrome-iron oxide interfaces. J. Phys. Chem. C 2007, 111 (30), 11363-11375.

23. Walker, S. L.; Bhattacharjee, S.; Hoek, E. M. V.; Elimelech, M. A novel asymmetric clamping cell for measuring streaming potential of flat surfaces. Langmuir 2002, 18, 2193-2198.

24. Boulos, L.; Prévost, M.; Barbeau, B.; Coallier, J.; Desjardins, R. LIVE/DEAD BacLight: application of a new rapid staining method for direct enumeration of viable and total bacteria in drinking water. $J$. Microbiol. Methods 1999, 37 (1), 77-86.

25. Deutsch, W. J. Groundwater geochemistry: fundamentals and applications to contamination. Lewis publishers: New York, 1997.

26. Poortinga, A. T.; Bos, R.; Norde, W.; Busscher, H. J. Electric double layer interactions in bacterial adhesion to surfaces. Surf. Sci. Rep. 2002, 47 (1), 1-32.

27. Elimelech, M.; Gregory, J.; Jia, X.; Williams, R. A. Particle deposition and aggregation Measurement, Modelling and Simulation. Elsevier: 1998.

28. Chen, G.; Walker, S. L. Role of solution chemistry and ion valence on the adhesion kinetics of groundwater and marine bacteria. Langmuir 2007, 23 (13), 7162-7169.

29. Sheng, X.; Ting, Y. P.; Pehkonen, S. O. The influence of ionic strength, nutrients and $\mathrm{pH}$ on bacterial adhesion to metals. J. Colloid Interface Sci. 2008, 321 (2), 256-264.

30. de Kerchove, A. J.; Elimelech, M. Bacterial swimming motility enhances cell deposition and surface coverage. Environ. Sci. Technol. 2008, 42 (12), 4371-4377.

31. Derjaguin, B. V.; Landau, L. Theory of the stability of strongly charged lyophobic sols and the adhesion of strongly charged particles in solutions of electrolytes. Acta Physicochim. U.S.S.R. 1941, 14, 733763.

32. Verwey, E. J. W.; Overbeek, J. T. G. Theory of the Stability of Lyophobic Colloids. Elsevier: Amsterdam, The Netherlands, 1948.

33. Abu-Lail, N. I.; Camesano, T. A. Role of ionic strength on the relationship of biopolymer conformation, DLVO contributions, and steric interactions to bioadhesion of Pseudomonas putida KT2442. Biomacromolecules 2003, 4 (4), 1000-1012.

34. Tufenkji, N. Application of a dual deposition mode model to evaluate transport of Escherichia coli D21 in porous media. Water Resour. Res. 2006, 42 (12), W12S11.

35. Record, M. T. J.; Courtenay, E. S.; Cayley, D. S.; Guttman, H. J. Responses of E. coli to osmotic stress: large changes in amounts of cytoplasmic solutes and water. Trends Biochem. Sci. 1998, 23 (4), 143148.

36. Gottenbos, B. The development of antimicrobial biomaterial surfaces. Ponsen \& Looijen: 2001.

37. Yamada, H.; Takahashi, N.; Okuda, S.; Tsuchiya, Y.; Morisaki, H. Direct observation and analysis of bacterial growth on an antimicrobial surface. Appl. Environ. Microbiol. 2010, 76 (16), 5409-5414.

38. Kugler, R.; Bouloussa, O.; Rondelez, F. Evidence of a charge-density threshold for optimum efficiency of biocidal cationic surfaces. Microbiol. 2005, 151 (5), 1341-1348. 
39. Gottenbos, B.; van der Mei, H. C.; Busscher, H. J.; Grijpma, D. W.; Feijen, J. Initial adhesion and surface growth of Pseudomonas aeruginosa on negatively and positively charged poly(methacrylates). J. Mater. Sci.: Mater. Med. 1999, 10 (12), 853-855.

40. Gottenbos, B.; Grijpma, D. W.; van der Mei, H. C.; Feijen, J.; Busscher, H. J. Antimicrobial effects of positively charged surfaces on adhering Gram-positive and Gram-negative bacteria. J. Antimicrob. Chemother. 2001, 48 (1), 7-13.

41. Jung, W. K.; Koo, H. C.; Kim, K. W.; Shin, S.; Kim, S. H.; Park, Y. H. Antibacterial activity and mechanism of action of the silver ion in Staphylococcus aureus and Escherichia coli. Appl. Environ. Microbiol. 2008, 74 (7), 2171-2178.

42. Dimkpa, C. O.; Calder, A.; Britt, D. W.; McLean, J. E.; Anderson, A. J. Responses of a soil bacterium, Pseudomonas chlororaphis $\mathrm{O} 6$ to commercial metal oxide nanoparticles compared with responses to metal ions. Environ. Pollut. 2011, 159 (7), 1749-1756.

43. Sadiq, I. M.; Chowdhury, B.; Chandrasekaran, N.; Mukherjee, A. Antimicrobial sensitivity of Escherichia coli to alumina nanoparticles. Nanomedicine: Nanotechnology, Biology and Medicine 2009, 5 (3), 282-286.

44. Seil, J. T.; Webster, T. J. Antibacterial effect of zinc oxide nanoparticles combined with ultrasound. Nanotechnology 2012, 23 (49), 495101.

45. Terada, A.; Okuyama, K.; Nishikawa, M.; Tsuneda, S.; Hosomi, M. The effect of surface charge property on Escherichia coli initial adhesion and subsequent biofilm formation. Biotechnol. Bioeng. 2012, 109 (7), 1745-1754.

46. Cai, P.; Huang, Q.; Walker, S. L. Deposition and survival of Escherichia coli O157:H7 on clay minerals in a parallel plate flow system. Environ. Sci. Technol. 2013, 47 (4), 1896-1903.

47. Ehrlich, H. L. Are gram-positive bacteria capable of electron transfer across their cell wall without an externally available electron shuttle? Geobiol. 2008, 6 (3), 220-224.

48. Beveridge, T. J. Role of cellular design in bacterial metal accumulation and mineralization. Annu. Rev. Microbiol. 1989, 43 (1), 147-171.

49. Williams, L. B.; Metge, D. W.; Eberl, D. D.; Harvey, R. W.; Turner, A. G.; Prapaipong, P.; PoretPeterson, A. T. What makes a natural clay antibacterial? Environ. Sci. Technol. 2011, 45 (8), 3768-3773.

50. Urrutia Mera, M.; Kemper, M.; Doyle, R.; Beveridge, T. J. The membrane-induced proton motive force influences the metal binding ability of Bacillus subtilis cell walls. Appl Environ Microbiol. 1992, 58 (12), $3837-3844$.

51. Iriberri, J.; Unanue, M.; Ayo, B.; Barcina, I.; Egea, L. Bacterial production and growth rate estimation from $\left[{ }^{3} \mathrm{H}\right]$ thymidine incorporation for attached and free-living bacteria in aquatic systems. Appl. Environ. Microbiol. 1990, 56 (2), 483-487.

52. Fletcher, M. The physiological activity of bacteria attached to solid surfaces. Adv Microb Physiol $1991,32,53-85$.

53. Hong, Y.; Brown, D. G. Variation in bacterial ATP level and proton motive force due to adhesion to a solid surface. Appl. Environ. Microbiol. 2009, 75 (8), 2346-2353.

54. $\quad$ van Loosdrecht, M. C.; Lyklema, J.; Norde, W.; Zehnder, A. J. Influence of interfaces on microbial activity. Microbiol. Mol. Biol. Rev. 1990, 54 (1), 75-87.

55. Marshman, N. A.; Marshall, K. C. Bacterial growth on proteins in the presence of clay minerals. Soil Biol. Biochem. 1981, 13 (2), 127-134.

56. Dashman, T.; Stotzky, G. Microbial utilization of amino acids and a peptide bound on homoionic montmorillonite and kaolinite. Soil Biol. Biochem. 1986, 18 (1), 5-14.

57. Kjelleberg, S.; Hermansson, M. Starvation-induced effects on bacterial surface characteristics. Appl. Environ. Microbiol. 1984, 48 (3), 497-503. 
58. Dawson, M. P.; Humphrey, B. A.; Marshall, K. C. Adhesion: A tactic in the survival strategy of a marine vibrio during starvation. Curr. Microbiol. 1981, 6 (4), 195-199.

59. Mozes, N.; Rouxhet, P. G. Dehydrogenation of cortisol by Arthrobacter simplex immobilized as supported monolayer. Enzyme Microb. Technol. 1984, 6 (11), 497-502.

60. Kenney, J. P. L.; Fein, J. B. Cell wall reactivity of acidophilic and alkaliphilic bacteria determined by potentiometric titrations and Cd adsorption experiments. Environ. Sci. Technol. 2011, 45 (10), 4446-4452. 


\section{TOC Graphic}

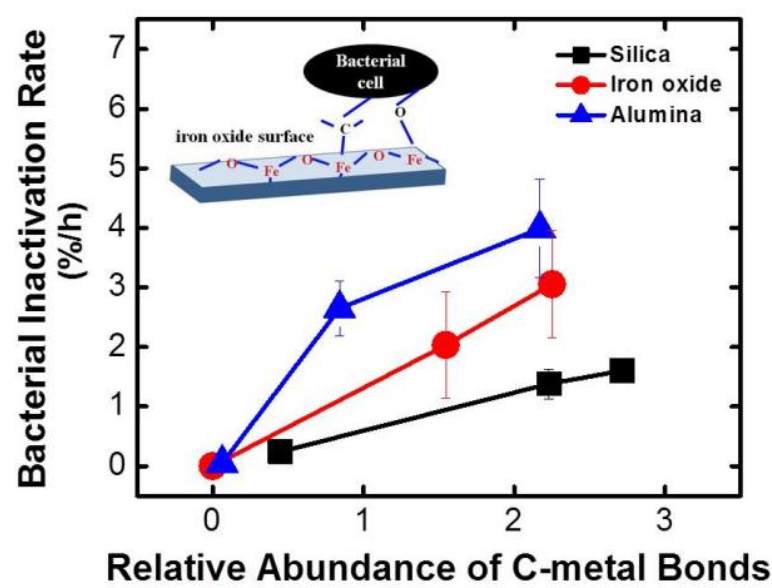

(\%) 